\title{
Correction to: DNA methylation studies in cattle
}

\author{
Jana Halušková ${ }^{1}$. Beáta Holečková ${ }^{1}$. Jana Staničová ${ }^{2}$
}

Published online: 2 March 2021

(C) Institute of Plant Genetics, Polish Academy of Sciences, Poznan 2021

\section{Correction to: Journal of Applied Genetics (2021) 62:121-136} https://doi.org/10.1007/s13353-020-00604-1

The author would like to add Funding in the back matter of the originally published article.

Funding This work was supported by the Scientific Grant Agency of Slovak Republik under grant number 1/0242/19.

The original article has been corrected.

Publisher's note Springer Nature remains neutral with regard to jurisdictional claims in published maps and institutional affiliations.

The online version of the original article can be found at https://doi.org/ 10.1007/s13353-020-00604-1

\footnotetext{
Jana Halušková

jana.haluskova@uvlf.sk
}

1 Department of Biology and Physiology, University of Veterinary

Medicine and Pharmacy in Košice, Komenského 73, 041

81 Košice, Slovak Republic

2 Department of Chemistry, Biochemistry and Biophysics, University of Veterinary Medicine and Pharmacy in Košice, Komenského 73, 04181 Košice, Slovak Republic 